\title{
Z-Score or S-Score Model is Better to Predict Financial Distress?: Test in State-Owned Enterprise Listed in IDX
}

\author{
B.I. Tristanti \& R. Hendrawan* \\ Telkom University \\ Bandung, Indonesia \\ riko_hendrawan@yahoo.com
}

\begin{abstract}
-this research investigated four stated-owned entreprise that have negative profit in 2016 and we investigated from 2012 to 2016 using Altman Z-Score and Springate S-Score. The probability of bankcruptcy for all company, several step are conducted in this research, the first stage of the calculation of the financial ratios analysis of each company obtained from audit results published by the company from 2012 to 2016. In the second stage of calculation and analysis are included in the formula ZScore and S- Score, In the third stage, we provide improvement advice to repair companies located in the gray area and distress category on Z-Score, and companies that fall into the high probability of bankruptcy category, if they have an S-Score below 0.862. Findings from this research show, there are two companies that experienced financial distress they are PT. Garuda Indonesia and PT. Krakatau Steel (<1.81) during 2012 to 2016, while PT. Aneka Tambang and PT. Indofarma must carefully maintain the performance of the company during the period of five years both companies have been included in the category of companies in the area of distress and gray area. Using $S$-Score, we found, there are three companies during 2012 until 2016, two companies into the high category bankruptcy that is PT. Garuda Indonesia and PT. Krakatau Steel. This indicates that both companies are likely to have substantial bankruptcy because they have an S-Score score below 0.862, for five consecutive years, while PT. Indofarma for four consecutive years from 2013 to 2016 has an S-Score value below 0.862 so it needs a comprehensive preventive measure to prevent the three companies from bankruptcy. The first suggestions is increasing company's operational efficiency and the second is avoid using debt to financing company.
\end{abstract}

Keywords—Z-Score; S-Score; Financial Distress

\section{INTRODUCTION}

State-Owned Enterprise becomes an important pillar in the driving of national economy. It should continue to grow in running its business and facing stiff competition. but based on data from 2017, from 24 state-owned companies listed on the Indonesia Stock Exchange there are four companies that experienced losses such as PT. Garuda Indonesia (GIAA), PT. Aneka Tambang (ANTM), PT. Indofarma (INAF) and PT. Krakatau Steel (KRAS). Bankruptcy become a worldwide problem and widely perceived to be disaster to the economy [1]. Indonesia has experienced facing great economic disaster in 1998 and in 2008. In 1998 IDX composite fell sharply and reached $-37.07 \%$. [2] Furthermore, A sharper decline of IDX occurred in 2008, it dropped sharply and reached $-59.31 \%$. There are five financial ratios and developed a Z-score bankruptcy prediction model, applied the Multiple Discriminant Analysis (MDA) approach to predict the financial distress of company and determined a cut point of Z- score (2.99) to classify healthy and distressed firms and the model that accuracy was $95 \%$ [3]. S-Score model, using 40 companies with an accuracy rating of $92.5 \%$ [4]. In later tests done by other academic researchers, a 50 Company test (with average assets of 2.5 million) showed $88 \%$ accuracy and a 24 Company Test (with average assets of 63.4 million) showed $83 \%$ accuracy. Research on corporate bankruptcy was undertaken by several research [5] [6] [7] [8] [9] [10] with different results. So this study aims to compare the application of Z-Score and S-Score models in predicting the bankruptcy of state-owned enterprises in Indonesia from 2012 to 2016.

\section{LITERATURE REVIEW}

\section{A). Z-Score Model}

The model was created by Altman [3], used data sample consisted of 66 firms, five key financial ratios and weighted by coefficients. He applied the statistical method of discriminant analysis to a data set of publicly held manufacturers. All businesses in the database were 
manufacturers, and small firms with an asset of $<\$ 1$ million were eliminated. The original $\mathrm{Z}$-score formula was as follows:

$$
\begin{aligned}
& \mathrm{Z}=1,2(\mathrm{X} 1)+1,42(\mathrm{X} 2)+3,3(\mathrm{X} 3)+0,6(\mathrm{X} 4)+ \\
& 0,999(\mathrm{X} 5) \text {. }
\end{aligned}
$$

Where:

$$
\begin{aligned}
& \text { X1 }=\text { Working Capital to Total Assets } \\
& \text { X2 } \text { Retained Earnings to Total Assets } \\
& \text { X3 }=\text { Earning Before Interest and Tax to } \text { Total Assets } \\
& \text { X4 }=\text { Market Value of Equity to Book Value } \\
& \text { of Debt } \\
& \text { X5 }=\text { Sales to Total Assets }
\end{aligned}
$$

The Z-Score conclusions :

If the $\mathrm{Z}$ score $>2.99$ then called zone "safe"

If the $\mathrm{Z}$ Score between $1.81<\mathrm{Z}<2.99$ it is called a "gray zone"

If the Z Score $<1.81$ is called the "distress" zone

\section{B). S-Score Model}

The model was proposed by Springrate [4], to predict distress of financial distress, Companies with a Springate score lower than 0.862 are classified as "high" probability of bankruptcy. The S-Score formula was as follows

\section{$S=1.03 A+3.07 B+0.66 C+0.4 D$.}

Where :

$$
\begin{aligned}
& \mathrm{A}=\text { Working Capital/ Total Assets } \\
& \mathrm{B}=\text { Earning Before Interest and Taxes (EBIT)/ } \\
& \\
& \text { Total Assets } \\
& \mathrm{C}=\text { Earning Before Taxes (EBT) } / \text { Currents } \\
& \quad \text { Liabilities) } \\
& \mathrm{D}=\text { Sales/ total assets }
\end{aligned}
$$

The S-Score conclusion :

If the S-Score > 0.862 then low probability of bankruptcy

If the S-Score $<0.862$ then high probability of bankruptcy

\section{METHOD}

The data used in the research is financial report data from 2012 to 2016 obtained from the company website, while stock prices obtained from the stock exchange website Indonesia to calculate the value of the stock market. After analyzed then the next calculation by using Z-Score and SScore to classify the company into the category of companies in accordance with the category Z-Score and SScore.

This research is comparative research, in the first stage of the calculation of the analysis of the financial ratios of each company obtained from audit results published by the company from 2012 to 2016. In the second stage of calculation and analysis are included in the formula $\mathrm{Z}$ -
Score and S- Score, on Z-score every company is entered into three categories, that is safe, gray area and distress company, whereas in S-Score every company is entered into two categories which is low probability of bankruptcy, if it has S-Score above 0,862 and high probability of bankruptcy if it has S-Score below 0.862 . In the third stage, we provide improvement advice to repair companies located in the gray area and distress category on Z-Score, and companies that fall into the high probability of bankruptcy category if they have an S-Score below 0.862 .

\section{RESEARCH FINDING AND DISCUSSION}

Based on table 1 below, shows that of the four companies, there are two companies from 2012 to 2016 into the category of distress company those are PT. Garuda Indonesia and PT. Krakatau Steel. This indicates that both companies are likely to have large bankruptcies because they have a Z-Score score below 1.81 for five consecutive years, so there is a need for a comprehensive preventive measure to keep both firms from bankruptcy. As for PT. Aneka Tambang and PT. Indofarma must carefully maintain the performance of the company because during the period of five years both companies have been included in the category of companies in the area of distress and gray area.

TABLE 1. Z-SCORE OF INDOFARMA, KARAKATAU STEEL, ANEKA TAMBANG AND GARUDA INDONESIA IN 2012-2016

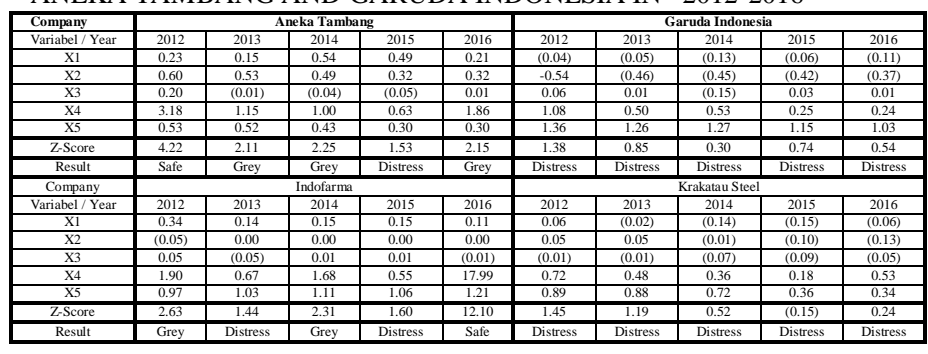

The same result also found using S-Score, shown in table 2 below, there are three companies from 2012 until 2016 there are two companies into the high category bankruptcy that is PT. Garuda Indonesia and PT. Krakatau Steel. This indicates that both companies are likely to have substantial bankruptcy because they have an S-Score score below 0.862 , for five consecutive years, while PT. Indofarma for four consecutive years from 2013 to 2016 has S-Score value below 0.862 so it needs a comprehensive preventive measure to prevent the three companies from bankruptcy. While PT. Indofarma for five consecutive years is in its low category of bankruptcy.

TABLE 2. S-SCORE OF INDOFARMA, KARAKATAU STEEL ANEKA TAMBANG AND GARUDA INDONESIA IN 2012-2016.

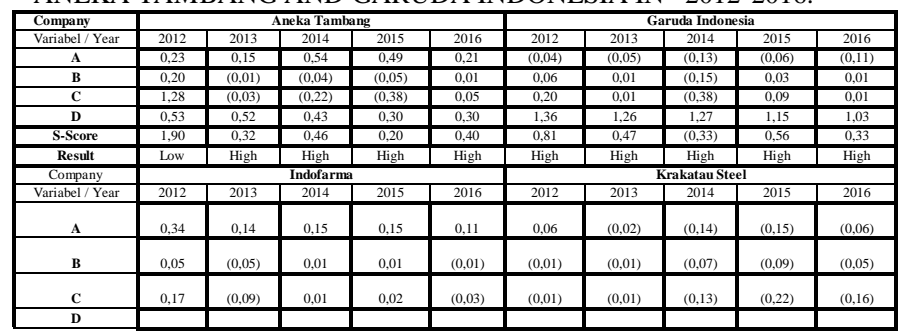




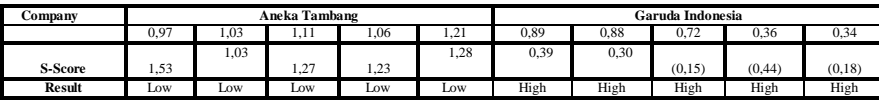

Findings from this research, Z-Score shows that, the main problem faced by PT. Garuda Indonesia and PT. Krakatau Steel, which is working capital to total assets and retained earning to total assets, indicates that both companies have problems with the need for working capital and the ability to generate net income, this is indicated by the negative value of the two variables. So the main thing to do is none other than to conduct operational efficiency comprehensively because it is the key to both companies avoid bankruptcy. Especially for PT. Krakatau steel, having a problem with operating profit, where EBIT to total assets has a negative value, then the use of funding from debt should be avoided, so as not to increase the burden of the company.

While the results of research using S-Score shows the same results for PT. Krakatau Steel, which has a problem in working capital to total assets, EBIT to total assets. More deeply on the S-Score model explains that Earning before tax (EBT) of PT. Krakatau Steel is no longer able to meet the current liability of the company, this is indicated from the negative value, so the company's EBT profit cannot meet for current liabilities, this indicates the inability of the company to pay its short-term liabilities. The same results were also found at PT. Garuda Indonesia, which has a problem with working capital to total assets, EBIT to total assets. What is interesting about the SScore Model occurs at PT. Aneka Tambang, which clearly in four consecutive years from 2013 to 2016 shows that PT. Aneka Tambang is classified at High Probability of Bankruptcy because it has S-Score below 0.862 , so it needs to do comprehensive performance improvement to improve company's financial performance, two main things that must be repaired by PT. Aneka Tambang are EBIT to total asset and EBT to current liabilities which have negative value, so the improvement step must be done on two things: operational efficiency of company and use of equity for company funding.

\section{CONCLUSION}

We investigated four stated-owned enterprises that have negative profit in 2016 and investigated from 2012 to 2016 using Altman ZScore and Springate S- Score the probability of bankruptcy, several step are conducted in this research, The first stage of the calculation of the analysis of the financial ratios of each company obtained from audit results published by the company from 2012 to 2016 . In the second stage of calculation and analysis are included in the formula Z- Score and S- Score, on Z-score every company is entered into three categories, that is safe, gray area and distress company, whereas in S-Score every company is entered into two categories which is low probability of bankruptcy if it has S-Score above 0,8 S-Score below 0.862 . In the third stage, we provide improvement advice to repair companies located in the gray area and distress category on Z-Score, and to companies that fall into the high probability of bankruptcy category if they have an S-Score below 0.862 . Findings from this research shows, there are two companies that experienced financial distress they are PT. Garuda Indonesia and PT. Krakatau Steel (<1.81) during 2012 to 2016, while PT. Aneka Tambang and PT. Indofarma must carefully maintain the performance of the company during the period of five years both companies have been included in the category of companies in the area of distress and gray area. Using S-Score, We found from 2012 until 2016 there are two companies into the high category bankruptcy that are PT. Garuda Indonesia and PT. Krakatau Steel. This indicates that both companies are likely to have substantial bankruptcy because they have an S-Score score below 0.862 , for five consecutive years, while PT. Indofarma for four consecutive years from 2013 to 2016 has an S-Score value below 0.862 so it needs a comprehensive preventive measure to prevent the three companies from bankruptcy. Our Suggestions are the first is increasing company's operational efficiency and the second is avoid using debt to financing the company. 


\section{REFERENCES}

[1] Kaufman GG (1996), "Bank Failures, Systematic Risk, and Bank Regulation." Cato Journal, Volume (16)1: 17:45.

[2] Hendrawan, Riko (2018), “Assessing Shock Volatility using Long Straddle Option Strategy: Evidence at IDX Composite", Jurnal Keuangan dan Perbankan (Journal of Finance and Banking), 22(1): 113.

[3] Altman, E. I. (1968). Financial Ratios, Discriminant Analysis and the Prediction of Corporate Bankruptcy. The Journal of Finance, 23 (4), 589-609.

[4] Springate, G. L. V. (1978). Predicting the possibility of failure in a Canadian firm (Unpublished master's thesis). Simon Fraser University, Canada.

[5] Scott, J. (1981). The probability of bankruptcy: A comparison of empirical predictions and theoretical models. Journal of Banking \& Finance, 5, 318-344.

[6] Cybinski, Patti, (2001). "Description, explanation, prediction the evolution of bankruptcy studies?", Managerial Finance, Vol. 27 Issue: 4, pp.29-44.

[7] Chava, Sudheer and Jarrow, Robert A.,(2004). Bankruptcy Prediction with Industry Effects, Review of Finance, Kluwer Academic Publishers, Vol. 8, pp. 537-569.

[8] Ebrahimi Kordlor, Ali, and Mehran Araabi (2011)."Reviewing the application of Altman Falmer, Springate, Zmijewski and Shirata Bankruptcy prediction models in predicting concessional facilities to companies admitted to Tehran Stock Exchange (Case Study Sepah Bank)" Accounting and Auditing Research, No. 12, Pp. 4-12.

[9] M. Fakhri Husein, E.I. (2014)," Precision of the models of Altman, Springate, Zmijewski, and Grover for predicting the financial distress". Journal of Economics, Business, and Accountancy Ventura Vol. 17, No. 3, December 2014, pages 405 - 416.

[10] Pakdaman, Hasan (2018), "Investigating the Ability of Altman and Springate and Zmijewski and Grover Bankruptcy Prediction Models in Tehran Stock Exchange". Espacios, Volume 39 (Number 140) 